\title{
A new species of Aciconula (Amphipoda, Senticauda, Caprellidae) from Sultan Iskandar Marine Park, Malaysia
}

\author{
Jacqueline H.C. Lim', B. Abdul Rahim Azman',2, B.H. Ross Othman ${ }^{3}$ \\ I School of Environmental \& Natural Resource Sciences, Faculty of Science and Technology, Universiti Ke- \\ bangsaan Malaysia, 43600 UKM Bangi, Selangor, Malaysia 2 Marine Ecosystem Research Centre (EKO- \\ MAR), Faculty of Science and Technology, Universiti Kebangsaan Malaysia, 43600 UKM Bangi, Selangor, \\ Malaysia 3 School of Marine and Environmental Sciences, Universiti Malaysia Terengganu, 21030 Kuala \\ Nerus, Terengganu, Malaysia
}

Corresponding author: B. Abdul Rahim Azman (abarahim@gmail.com)

Academic editor: Alan Myers | Received 23 January 2019 | Accepted 14 May 2019 | Published 2 July 2019

http://zoobank.org/F293A34B-5874-4E69-B991-DAB74038FB00

Citation: Lim JHC, Azman BAR, Othman BHR (2019) A new species of Aciconula (Amphipoda, Senticauda, Caprellidae) from Sultan Iskandar Marine Park, Malaysia. ZooKeys 859: 17-29. https://doi.org/10.3897/ zookeys.859.33284

\begin{abstract}
A new species of caprellid, Aciconula tinggiensis (Amphipoda, Senticaudata, Caprellidae) was discovered from Pulau Tinggi, Sultan Iskandar Marine Park (SIMP), South China Sea, Malaysia. The new Malaysian species can be distinguished from the other Aciconula species by the combination of the following characters: 1 . the presence of a very small suture between head and pereonite $1 ; 2$. antenna 1 flagellum with 4 articles; 3. inner lobe of lower lip unilobed; 4 . gnathopod 2 palm of propodus with a large proximal projection (stretching from the proximal margin of the palm to nearly mid-way of palm); 5. pereopods 3-4 with 2 articles (article 1 subrectangular, article 2 conical or tapering at the tip with 1 plumose seta and 2 normal setae) and; 6. pereopod 5 covered with relatively dense and long setae. An updated identification key for the five known species in the genus, including information on the respective geographical distribution and habitat, is presented.
\end{abstract}

\section{Keywords}

Aciconula tinggiensis sp. nov., caprellid, new species, taxonomy, South China Sea

Copyright Jacqueline H.C. Lim et al. This is an open access article distributed under the terms of the Creative Commons Attribution License (CC BY 4.0), which permits unrestricted use, distribution, and reproduction in any medium, provided the original author and source are credited. 


\section{Introduction}

The amphipod genus Aciconula was established by Mayer (1903) with A. miranda Mayer, 1903 as its type species. However, the exact diagnostic characteristics of this genus were unclear because the types described by Mayer (1903) for this genus were both females (that were collected from three different localities: Singapore, Malaysia and Koh Krau, Thailand) and only figures of the whole body, pereopod 3, pereopod 4, pereopod 5, mandibular palp article 3 and maxilliped were drawn. Mayer (1912) then described a male but the abdomen and mouthparts were also not included. Nevertheless, general morphology of the male specimen agrees well with the type and the rest of the appendages such as pereopods 3 to 7 are also similar to the female. The abdomen was also left out. Following that, Arimoto (1976) referred to Utinomi's (1969) description based on specimens collected from Kii Peninsula, Japan and revised its generic diagnosis. Subsequently, three more species of Aciconula were reported; Aciconula acanthosoma Chess, 1989 from southern California; A. australiensis Guerra-García, 2004 from Western Australia and most recently A. tridentata Guedes-Silva \& Souza-Filho, 2013 described from Pernambuco, Brazil.

The Sultan Iskandar Marine Park (SIMP) is one of Malaysia's marine protected areas located 15-65 km from Mersing, off the north-east coast of the Johor State, Malaysia in the South China Sea. This body of water covering an area of about 8000 hectares holds one of the most diverse marine ecosystems on the east coast of Peninsular Malaysia, ranging from sandy shores, coral reefs, mangroves, estuaries, mudflats to seagrass and open water habitats (see Harborne et al. 2000; Japar Sidik and Muta Harah 2003; Maritime Institute of Malaysia 2006; Japar Sidik et al. 2006; Azman et al. 2008; Japar Sidik and Muta Harah 2011; Lim et al. 2015). The SIMP (Fig. 1) consists of 13 main islands namely Pulau Harimau, Pulau Mensirip, Pulau Goal, Pulau Besar, Pulau Tengah, Pulau Hujung, Pulau Rawa, Pulau Tinggi, Pulau Mentinggi, Pulau Sibu, Pulau Sibu Hujung, Pulau Pemanggil and Pulau Aur. This paper continues the previous significant contributions on the biodiversity of SIMP and its vicinity including Othman and Azman (2007), Lim et al. (2010), Gan et al. (2010), Azman and Melvin (2011), Lim et al. (2012), Azman and Othman (2013), Chew et al. (2014), Tan et al. (2014, 2015), Lim et al. (2015), Chew et al. (2016) Lim et al. (2017) and Tan and Azman $(2017,2018)$ on marine crustaceans. The present paper also deals with the detailed description of this new species; an updated identification key to all the known Aciconula species is also given.

\section{Material and methods}

\section{Sampling}

The caprellids examined in this study were collected from an artificial reef of Kampung Pasir Panjang, Pulau Tinggi, Sultan Iskandar Marine Park (SIMP) at 9-11 m water depth (Fig. 1). Collections were made by SCUBA; hosts (stinging hydroids) together with attached caprellids were put into fine mesh bags. Specimens used for morphological descriptions were preserved in $4 \%$ formaldehyde before examination. 


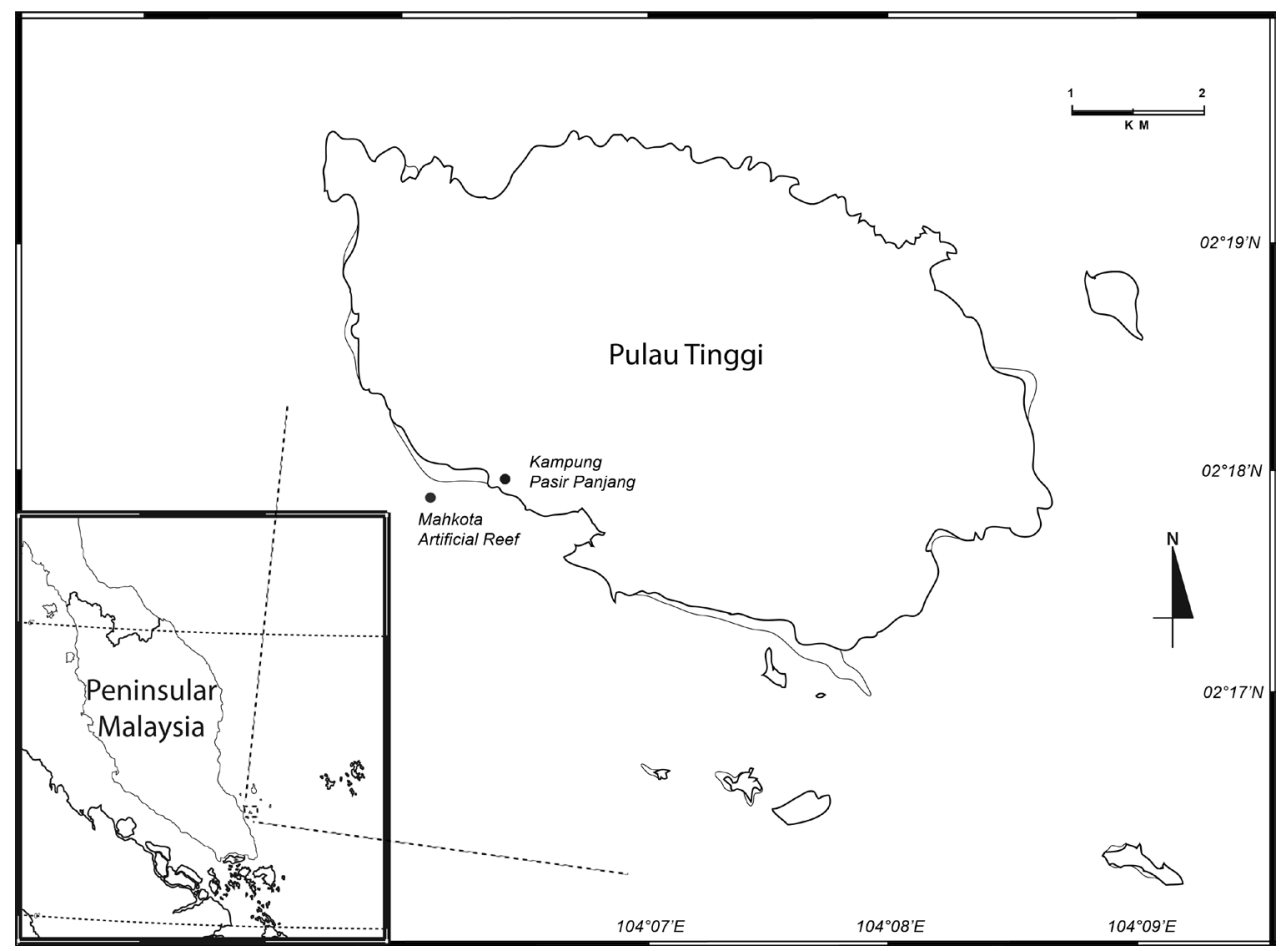

Figure I. Pulau Tinggi of Sultan Iskandar Marine Park (SIMP), Malaysia.

\section{Laboratory procedures}

Appendages were dissected from the right side of the specimens and stored in several semi-permanent slides mounted in glycerol and then drawn under an optical microscope (Olympus BX43) and a stereomicroscope with a camera lucida. The drawings were digitized on Adobe Illustrator CS3 using the methods described in Coleman (2003). All materials are deposited at the South China Sea Research and Repository Centre, Institute of Oceanography and Environment, Universiti Malaysia Terengganu, 21030 Kuala Nerus, Terengganu, Malaysia (UMT Crus). The following abbreviations are used in the figures: $\mathbf{A}$, antenna; $\mathbf{A B D}(\mathbf{L})$, abdomen lateral view; $\mathbf{A B D}(\mathbf{V})$, abdomen ventral view; $\mathbf{G}$, gnathopod; LL, lower lip; $\mathbf{M D}$, mandible; MX, maxilla; MXP, maxilliped; P, pereopod; UL, upper lip; $\mathbf{R}$, right; $\mathbf{L}$, left; $\widehat{\jmath}$, male; + , female.

\section{Systematics}

Order AMPHIPODA Latreille, 1816

Suborder COROPHIIDEA Leach, 1814

Family CAPRELLIDAE Leach, 1814

Genus Aciconula Mayer, 1903 


\section{Aciconula tinggiensis sp. nov.}

http://zoobank.org/DEE62918-DA9C-4090-9245-872B7D982DBD

Figs 2-5

Etymology. Named after the type locality, Pulau Tinggi in SIMP, Malaysia.

Material examined. Holotype: male, $2.2 \mathrm{~mm}$, UMT Crus 01003, Mahkota artificial reef Pulau Tinggi, SIMP, Johor, $02^{\circ} 17.637^{\prime} \mathrm{N}, 104^{\circ} 05.817^{\prime} \mathrm{E}$, SCUBA diving, 9 June 2009, 12.31 PM, depth 10.7 m, coll. Azman, B.A.R., Gan, S.Y., Lim, J.H.C., Chew, M.W.H. \& Shamsul, B.

Paratypes: 1 female, UMT Crus 01004 (Fig. 4); 2 males, 1 female, UMT Crus 01005; 2 males, 2 females, UMT Crus 01006; 2 males, 2 females, 1 juvenile, UMT Crus 01007; same station data.

Type locality. Mahkota artificial reef, Pulau Tinggi, SIMP, Malaysia.

Description. [Based mostly on holotype (UMT Crus 01003), $2.2 \mathrm{~mm}$, supplemented by paratype (UMT Crus 01004), $1.8 \mathrm{~mm}$ for female and (UMT Crus 01005) for lower lip and maxilliped]

Adult male. Body length, $2.2 \mathrm{~mm}$. UMT Crus 01003. Head/pereonite 1 without dorsal projection. Head length $0.2 \mathrm{~mm}$; pereonite $1,0.07 \mathrm{~mm}$; head and pereonite 1 partially fused (suture clear); pereonite $2,0.34 \mathrm{~mm}$ with an acute mid-dorsal projection; pereonite 3 longest, $0.53 \mathrm{~mm}$; pereonite $4,0.44 \mathrm{~mm}$; pereonite $5,0.41 \mathrm{~mm}$, subequal in length to pereonite 4; pereonite 6, $0.16 \mathrm{~mm}$; pereonite 7 short, $0.12 \mathrm{~mm}$. Eye small. Antenna 1 about $0.4 \times$ body length; peduncular article 1 with tuft of plumose setae; peduncular article 2 longest; peduncular article 3 lobed at posterodistal margin; flagellum approximately half of peduncular length with 4 articles, proximal article composed of 2 articles. Antenna 2 about $0.4 \times$ the length of antenna 1 ; peduncular articles lobus; flagellum 2-articulate.

Lower lip outer lobes with pair of ducts; inner lobes unilobed. Mandible left incisor with 6 teeth; lacinia mobilis plate like and serrated distally; accessory setal row with 3 setae; mandibular molar present without robust teeth; palp 3-articulate with distal article comprising a row of 5 teeth and setal formula of 1-3-1, second article of palp without seta on inner distal margin; right incisor with 5 teeth; lacinia mobilis with 7 teeth; accessory setal row with 2 setae; palp 3 -articulate with distal article comprising a row of 5 teeth and setal formula of 1-3-1, second article of palp with one seta on inner distal margin. Maxilla 1 outer plate with 5 cuspidate and denticulate spines (robust apical setal-teeth); palp article 2 long, $4 \times$ length of article 1 with 3 setae apically. Maxilla 2 inner plate with 4 short and long setae distally; outer plate $1.3 \times$ length of inner plate with 5 slender setae apically. Maxilliped inner plate small, with one short and one long apical setae; outer plate about $2.5 \times$ inner plate with 3 setae at distal margin; palp 4-articulate, scarcely setose, article 2 with 1 seta at inner distal margin, article 3 with 5 distal setae; article 4 tapering to a tip with 2 setae distally and 1 seta at outer proximal margin.

Pereon. Gnathopod 1 basis longer than ischium, merus and carpus combined; propodus subtriangular, longer than wide, scarcely setose, palm with a pair of grasping spines; dactylus falcate, provided with fine setae along lateral margin, tip of dactylus bifid. Gnathopod 2 begins 1/4-way along anterior margin of pereonite 2; basis about 
$0.7 \times$ pereonite 2 ; ischium and merus subquadrate; carpus triangular; propodus $1.6 \times$ as long as wide, $1.3 \times$ length of basis, palm with large proximal projection (stretching from proximal margin of palm to nearly mid-way of palm), provided with one robust grasping spine proximally, a small triangular projection medially and ending with a triangular projection provided with 1 seta, distal margin of palm with 1 triangular projection; dactylus falcate, fitting on palm.

Gill 3 length $0.2 \times$ corresponding pereonite, oval. Pereopod 3 reduced, about $0.5 \times$ gill length, 2-articulate, second article with one plumose seta and two simple setae apically. Gill 4 slightly larger than gill 3, $0.3 \times$ corresponding pereonite, oval. Pereopod 4 reduced, about $0.5 \times$ gill length, 2 -articulate, second article of pereopod 4 more slender than article 2 of pereopod 3 with one plumose seta and two simple setae apically. Pereopod 5, 6-articulate, curved upwards anterodorsally and extending past pereonite 4, setose entire margin comprising short and very long setae, carpus and propodus subequal in length, dactylus reduced to a small cone with one plumose seta apically. Pereopod 6 propodus with a pair of grasping spines proximally, dactylus falcate with one plumose seta on anterior margin at proximal region. Pereopod 7 similar with pereopod 6 but more robust than pereopod 6 .

Pleon. Uropod 1 vestigial with 4 setae; Uropod 2 vestigial with 2 setae distally and one facial seta on inner margin. Telson with one seta apically.

Adult female. Body length, $1.8 \mathrm{~mm}$. UMT Crus 01004. Head length $0.2 \mathrm{~mm}$; pereonite $1,0.04 \mathrm{~mm}$; head/pereonite 1 without dorsal projection; pereonite $2,0.29$ $\mathrm{mm}$ with rounded mid-dorsal projection; pereonite $3,0.39 \mathrm{~mm}$; pereonite $4,0.32$ $\mathrm{mm}$ with acute dorsodistal projection; pereonite $5,0.38 \mathrm{~mm}$, subequal in length to pereonite 3; pereonite $6,0.13 \mathrm{~mm}$; pereonite 7 short, $0.08 \mathrm{~mm}$. Eye small. Antenna 1 about $0.4 \times$ body length; peduncular article 1 with tuft of setae; peduncular article 2 longest; peduncular article 3-lobed at posterodistal margin; flagellum approximately $1.8 \times$ peduncular length with 4 articles. Antenna 2 about $0.4 \times$ the length of antenna 1; peduncular articles lobus; flagellum 2-articulate.

Mouthparts of the female are similar to those of male (refer to male mouthparts).

Pereon. Gnathopod 2 basis begins 1/4-way along anterior margin of pereonite 2; basis about $0.7 \times$ pereonite 2 ; ischium and merus subquadrate; carpus subtriangular; propodus $2.4 \times$ as long as wide, $1.2 \times$ length of basis, palm without large proximal projection, provided with one robust grasping spine distally; dactylus falcate, fitting on palm. Gill 3 length $0.3 \times$ corresponding pereonite, oval. Pereopod 3 reduced, about $0.5 \times$ gill length, 2 -articulate, similar with the male, second article with one plumose setae and two simple setae apically. Gill 4 subequal with gill 3, $0.4 \times$ corresponding pereonite, oval. Pereopod 4 reduced, about $0.4 \times$ gill length, 2 -articulate, subequal with pereopod 3 with one plumose setae and two simple setae apically. Oostegites on pereonite 3 and 4 with setae. Pereopod 5, 6-articulate, curved upwards anterodorsally and extending past pereonite 4, more slender than male pereopod 5, setose entire margin comprising short and very long setae, propodus longest, dactylus reduced to a small cone with one plumose seta apically.

Pleon. Uropod 1 vestigial with 1 simple setae; Uropod 2 vestigial with 1 setae distally. Telson with one plumose seta apically. 
Remarks. Considering the four reported species from the genus Aciconula, A. tinggiensis sp. nov. is most similar to $A$. australiensis in terms of antenna 1 and 2, gnathopod 1, mouthparts (maxilliped and maxillas) and abdomen. Pereopods 3 and 4 of the male are also similar except for the presence of a seta on article 1 of A. australiensis. The Malaysian specimen differs from the Australian counterpart in terms of the absence of 1 ) a head projection (present in $A$. australiensis); 2) inner lobe of lower lip unilobed (A. australiensis bilobed); 3) gnathopod 2 propodus proximal projection shallow and wide, about $1 / 2$ of palm (A. australiensis more pronounced, about $1 / 3$ of palm); 4) pereopod 3 of female similar to the male with only 2 articles while $A$. australiensis shows sexual dimorphism with 3 articles; 5) longer (articles 4 and 5 about $2 \times$ longer) pereopod 5, $0.43 \times$ body length, terminal article with one plumose seta and generally more setose $(A$. australiensis only $0.23 \times$ body length; terminal articles with one normal seta); 6) mandibles with setal formula of 1-3-1 (setal formula 1-4-1 in A. australiensis).

Aciconula acanthosoma Chess, 1989 clearly differs from the Malaysian specimen firstly by its numerous dorsal projections throughout its body, maxilliped inner lobes more robust and wide, terminally with one tooth and three setae (slender with two normal setae in $A$. tinggiensis sp. nov.), maxilla 2 with very short terminal setae and mandibles with large, well-developed molar and palp with setal formula of 1-6-1. Apart from its body armature and mouthparts, it also varies in terms of appendages such as gnathopod 2 (basis with a distolateral projection, palmar margin of propodus with a proximal projection followed by a strong spine and a deep sinus), pereopod 5 with short and fine dense setae (setae longer and less extensive in $A$. tinggiensis sp. nov. ), and abdomen with one pair of well-developed, 1-articulate abdominal appendage. The species from southern California is also much larger than the present specimen $(3.3 \times$ longer $)$ and the other two existing species from the Indo-Pacific. In spite of this, A. acanthosoma does have a few similarities in pereopods 3 and 4 with 2 articles and article 2 conical (except for the 3 terminal plumose setae) and pereopods 6 and 7 with 7 articles and grasping structure on article 6 . There is more dissimilarity in these two species than similarities. According to Guerra-García (2004), A. acanthosoma could be placed in a new genus based on the abdominal appendages and several mouthparts but presently there is only one genus, which exhibits the soft and flexible character of pereopod 5, therefore it is retained in the genus Aciconula.

The female specimen of $A$. tinggiensis sp. nov. was primarily used to compare with Mayer's (1903) type and Mayer's (1912) account of $A$. miranda because he only provided more detailed description and figures of females compared to males. Females of A. tinggiensis sp. nov. are similar to $A$. miranda Mayer, 1903 based on a single dorsal projection on pereonite 2 , antenna 1 flagellum with 4 articles, pereopod 4 with 2 articles (similar in shape and terminally with one plumose seta), and its gill shape. However, the present species (female) differs from A. miranda Mayer, 1903 in its pereopod 5 which has longer but less dense setae (more densely setose in $A$. miranda); pereopod 3 with 2 articles ( 3 articles in $A$. miranda); and pereopod 3 article 2 is conical and short (article 2 is subcylindrical with several seta marginally). Mouthparts of $A$. tinggiensis 


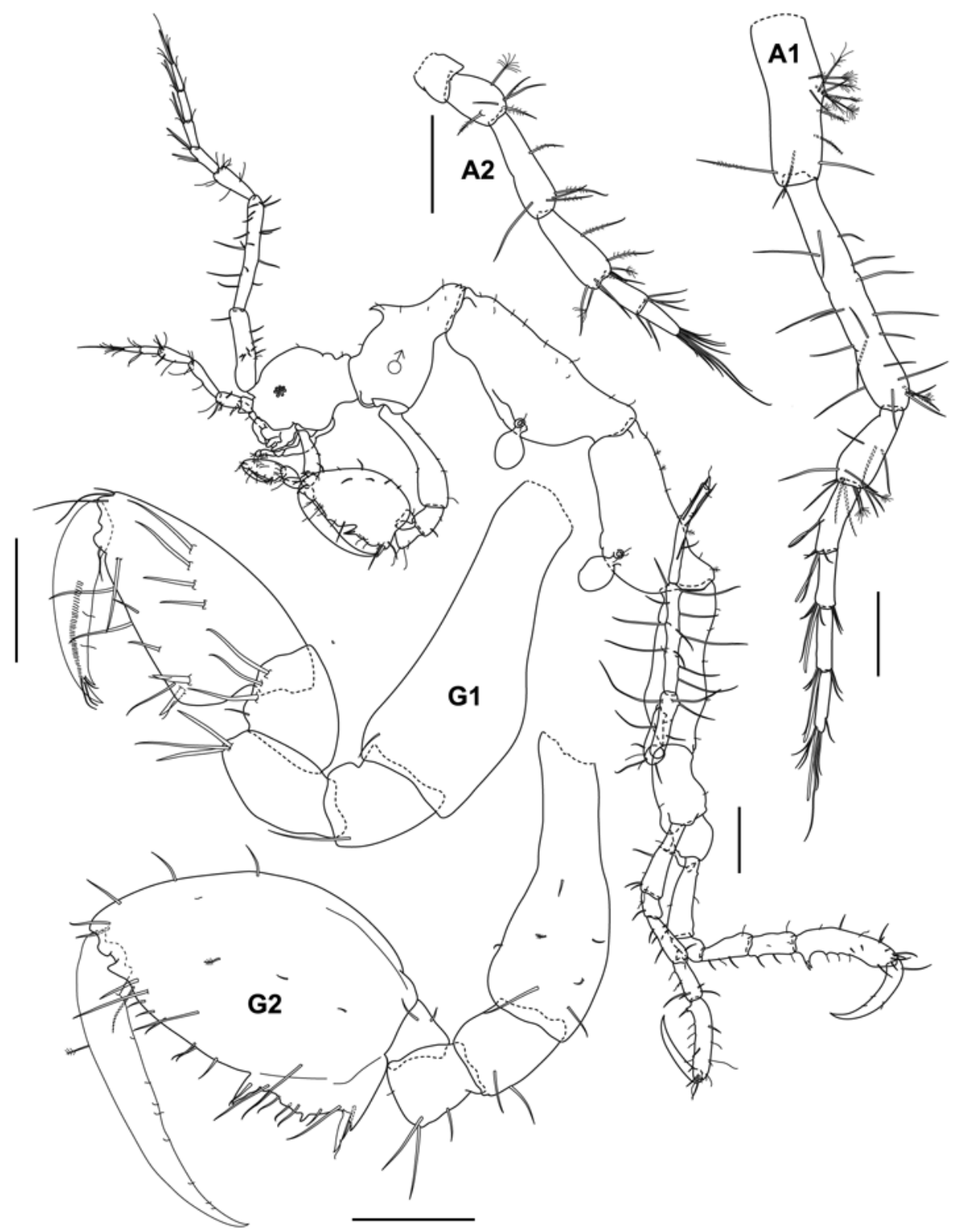

Figure 2. Aciconula tinggiensis sp. nov., male holotype, $2.2 \mathrm{~mm}$, UMT Crus 01003, Mahkota artificial reef, Pulau Tinggi, SIMP. Scales bars: $0.1 \mathrm{~mm}$ (A1, A2, G2); $0.05 \mathrm{~mm}$ (G1); $0.2 \mathrm{~mm}$ (whole body).

sp. nov. for males and females are similar therefore only the male mouthparts are used for comparison with Mayer's (1903) description and figures. Aciconula tinggiensis sp. nov. differs from $A$. miranda in terms of the setal formula of the mandibular palp 1-3-1 (setal formula 1-7-1 in A. miranda) and maxilliped outer plate with only 3 distal setae (maxilliped entire inner margin lined with setae in $A$. miranda). 


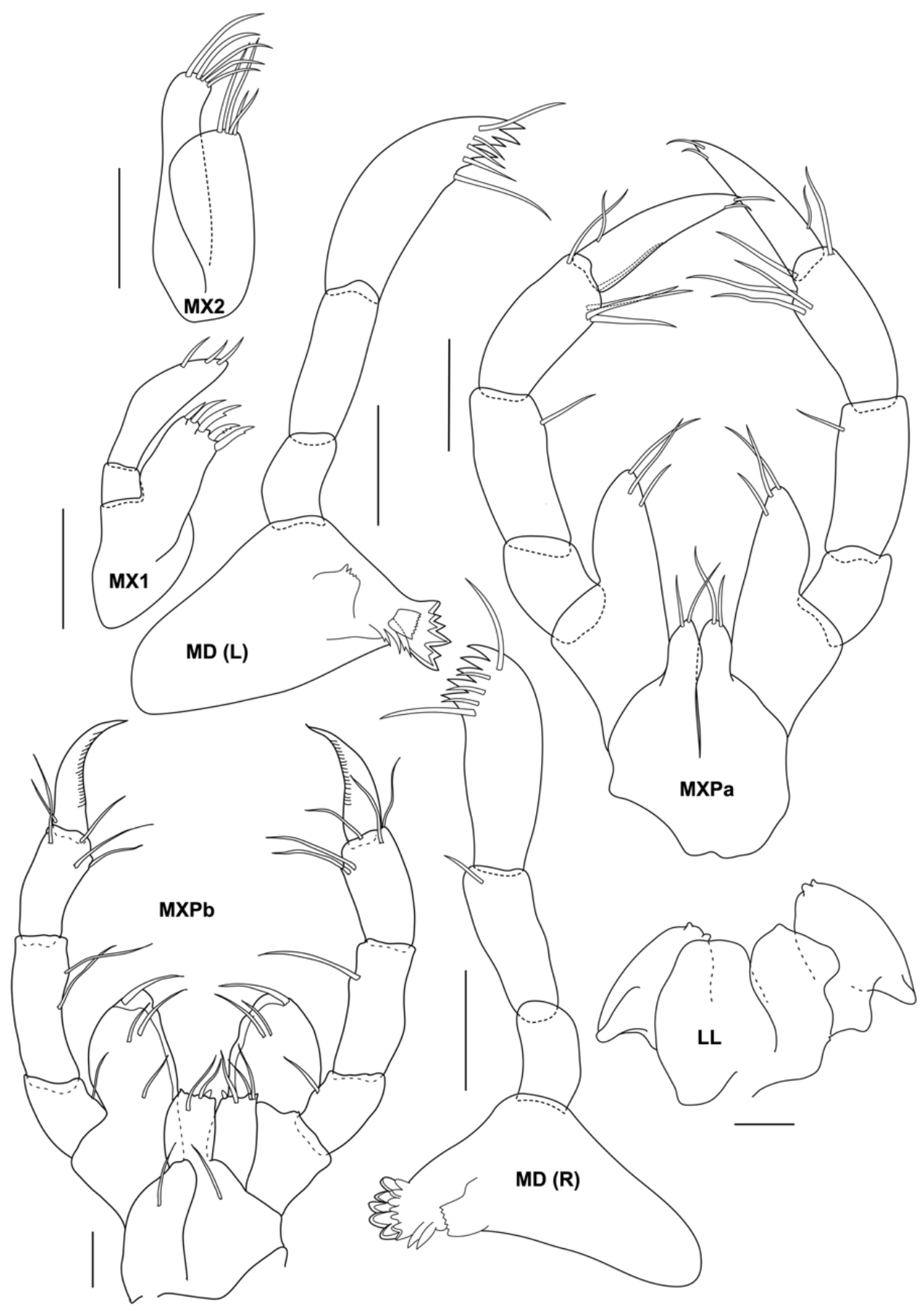

Figure 3. Aciconula tinggiensis sp. nov., male holotype, $2.2 \mathrm{~mm}$, UMT Crus 01003, Mahkota artificial reef, Pulau Tinggi, SIMP. Lower lip (LL) and MXPb from male paratype, UMT Crus 01005. Scale bars: $0.025 \mathrm{~mm}$ 


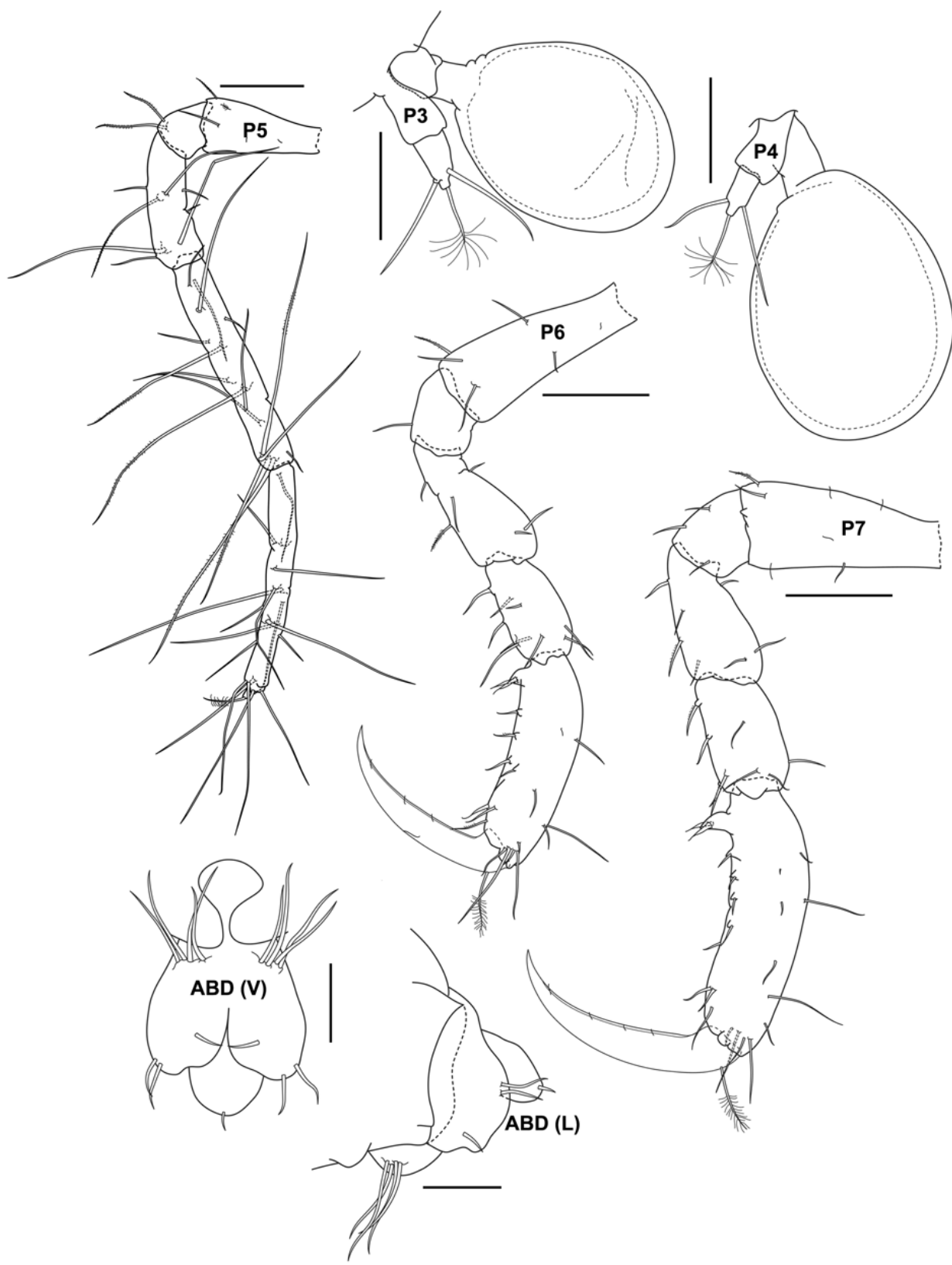

Figure 4. Aciconula tinggiensis sp. nov., male holotype, $2.2 \mathrm{~mm}$, UMT Crus 01003, Mahkota artificial reef, Pulau Tinggi, SIMP. Scale bars: 0.025 mm (ABD); 0.05 mm (P3, P4); 0.1 mm (P5, P6, P7).

Aciconula tridentata Guedes-Silva \& Souza-Filho, 2013 reported from Brazil, is similar to the present species in the: 1) presence of a small sharp median forward projection of the head; 2) pereopods 3 and 4 of male with two-articles, and absence of abdominal 


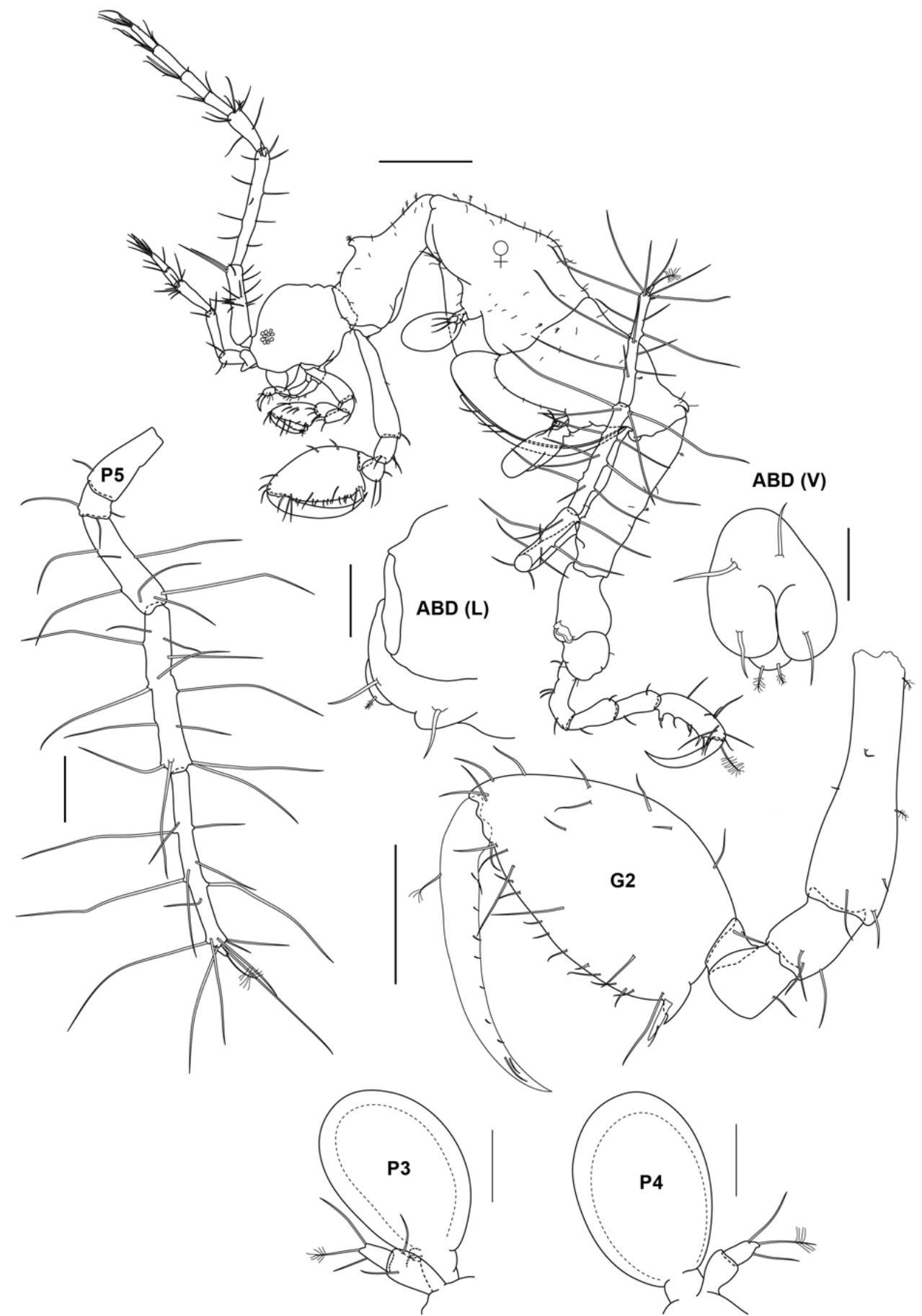

Figure 5. Aciconula tinggiensis sp. nov., female paratype, $1.8 \mathrm{~mm}$, UMT Crus 01004, Mahkota artificial reef, Pulau Tinggi, SIMP. Scale bars: 0.025 mm (ABD); $0.1 \mathrm{~mm}$ (G2, P5); 0.05 mm (P3, P4); $0.2 \mathrm{~mm}$ (whole body). 
appendages but differs in the length of the outer plate of maxilliped (longer in Aciconula tinggiensis sp. nov. reaching the mid-length of palp article 2), the sculpturing on the palm of male gnathopod 2, (with a 3-dentate projection, followed by a large excavation leading to a projection with two sharp processes in $A$. tridentata) and number or articles in female pereopods 3 and 4 (pereopod 34 -articulate and pereopod 4 -articulate in A. tridentata)

In conclusion, Aciconula tinggiensis sp. nov. described here is recognized as distinct from the four existing species of this genus based on these combination of characters; 1) a very small suture between head and pereonite $1 ; 2$ ) antenna 1 flagellum with 4 articles, its setal formula of 1-3-1;3) unilobed inner lobe of lower lip with pair of ducts on outer lobe; 4) gnathopod 2 palm of propodus with a large proximal projection, (stretching from the proximal margin of the palm to nearly mid-way of palm) provided with one robust grasping spine proximally, a small triangular projection medially and ending with a triangular projection provided with 1 seta; 5) pereopods 3 and 4 with 2 articles (article 1 subrectangular, article 2 conical or tapering at the tip with 1 plumose seta and 2 normal setae); 6) pereopod 5 covered with relatively dense and long setae; and 7) abdomen region with penes situated medially, uropod 2 degenerated into 4 setae, uropod 2 degenerated into 1 seta medially and 2 setae distally.

Habitat. The specimens have been found from 10-12 meters deep, living on stinging hyroids.

Distribution. Currently only known from Pulau Tinggi, Johor, Malaysia.

\section{Key to the species of the genus Aciconula Mayer, 1903}

1 Body dorsally strongly spinose, abdominal appendages present

A. acanthosoma Chess, 1989

Body dorsally not spinose, abdominal appendages absent

.2

(1) Head lacking a small sharp median forward projection

A. miranda Mayer, 1903

- $\quad$ Head with a small sharp median forward projection 3

3 Antenna 1 article 1 bearing a setose hump proximally

A. australiensis Guerra-Garcia, 2004

- $\quad$ Antenna 1 article 1 lacking setose hump proximally.................................... 4

$4 \quad$ Gnathopod 2 male first half of propodus palm bearing a 3-dentate followed by a large excavation ........A. tridentata Guedes-Silva \& Souza-Filho, 2013 - $\quad$ Gnathopod 2 male first half of propodus palm without dentation

A. tinggiensis sp. nov.

\section{Acknowledgments}

The authors would like to thank Shamsul B., Melvin C.W.H. and Ms. Gan S.Y. for their assistance in the field. Many thanks are also due to Sultan Iskandar Marine Park 
and Marine Park Section, Department of Fisheries, Malaysia. This study was supported by the Universiti Kebangsaan Malaysia research grant (LIV-2015-02) and the Japan Society for the Promotion of Science (JSPS) Core-to-Core Program (B.AsiaAfrica Science Platforms).

\section{References}

Arimoto I (1976) Taxonomic studies of caprellids (Crustacea, Amphipoda, Caprellidae) found in the Japanese and adjacent waters. Special Publications from the Seto Marine Biological Laboratory 3: 1-229. https://doi.org/10.5134/176456

Azman BAR, Ramlan O, Wan-Lotfi WM, Zaidi C, Othman BHR (2008) Seagrass biodiversity of Pulau Tinggi, Johor. In: Mohamed CAR, Sahrani FK, Ali MM, Zaidi CC, Norhayati A (Eds) Malaysia marine ecosystem: The studies of Johor Darul Takzim east coast. Research and Information Series of Malaysian Coasts, Malaysia, 1-176.

Azman BAR, Melvin CWH (2011) Two new species of Urothoe (Crustacea, Amphipoda, Gammaridea) from the east Johor Islands Archipelago, Malaysia. Zookeys 87: 43-62. https:// doi.org/10.3897/zookeys.87.817

Azman BAR, Othman BHR (2013) Shallow water marine gammaridean amphipods of Pulau Tioman, Malaysia, with the description of a new species. ZooKeys 335: 1-31. https://doi. org/10.3897/zookeys.335.5567

Chess JR (1989) Aciconula acanthosoma, new species, a caprellid amphipod from Southern California, with notes on its ecology. Journal of Crustacean Biology 9: 662-665. https:// doi.org/10.2307/1548595

Chew M, Abdul Rahim A, Haji Ross OB (2014) Tinggianthura alba: A new genus and species of Anthuridae (Isopoda, Cymothoida, Anthuroidea) from Pulau Tinggi, Johor, Malaysia with an updated key to the genera of Anthuridae. PLoS One 9: e99072. https://doi. org/10.1371/journal.pone.0099072

Chew M, Rahim ABA, Mohd Yusof NYB (2016) Two new species of Pendanthura (Isopoda, Cymothoida, Anthuroidea) from the east coast of Peninsular Malaysia with an identification key to the species of Pendanthura. Bulletin Marine Science 92: 229-242. https://doi. org/10.5343/bms.2015.1056

Coleman CO (2003) "Digital inking": How to make perfect line drawings on computers. Organisms Diversity and Evolution 3(14): 1-14. https://doi.org/10.1078/1439-6092-00081

Gan SY, Azman BAR, Yoshida T, Majid AM, Toda T, Takahashi K, Othman BHR (2010) Comparison of day and night mysid assemblages in a seagrass bed by using emergence traps, with key to species occuring at Pulau Tinggi, Malaysia. Coastal Marine Science 34: 74-81.

Guedes-Silva E, Souza-Filho J (2013) A new species of Aciconula (Amphipoda: Corophiidea) from Brazilian waters. Journal of the Marine Biological Association of the United Kingdom 93(7): 1835-1841. https://doi.org/10.1017/S0025315413000155

Guerra-García JM (2004) The Caprellidea (Crustacea: Amphipoda) from Western Australia and Northern Territory, Australia. Hydrobiologia 522: 1-74. https://doi.org/10.1023/ B:HYDR.0000029929.07691.a7 
Harbone A, Fenner D, Barnes D, Beger A, Harding M, Roxburgh ST (2000) Status report on the coral reefs of the east coast of Peninsular Malaysia. Coral Cay Conservation Limited, London, 89 pp.

Japar Sidik B, Muta Harah Z (2003) The seagrasses of Malaysia. In: Green EP, Short FT (Eds) World Atlas of Seagrasses. University of California Press, Berkeley, 152-160.

Japar Sidik B, Muta Harah Z (2011) Seagrasses - diversity, values and why they are declining. In: Ibrahim K, Mohamed CAR, Jamaludin MR, Kee AAA, Zulkifli FA, Lee JN (Eds) Malaysia's Marine Biodiversity: Inventory and Current Status. Department of Marine Park Malaysia, Putrajaya, 71-89.

Japar Sidik B, Muta Harah Z, Arshad A (2006) Distribution and significance of seagrass ecosystems in Malaysia. Aquatic Ecosystem Health \& Management 9: 203-214. https://doi. org/10.1080/14634980600705576

Latreille PA (1816) Chevrolle. Nouveau dictionnaire d'histoire naturelle Paris 6: 433-4.

Leach WE (1814) Article Crustaceology. The Edinburgh Encyclopaedia 7: 429-437.

Lim JHC, Azman BAR, Othman BHR (2010) Melitoid amphipods of the genera Ceradocus Costa, 1853 and Victoriopisa Karaman and Barnard, 1979 (Crustacea: Amphipoda: Maeridae) from the South China Sea, Malaysia. Zootaxa 2384: 23-39 https://doi.org/10.11646/ zootaxa.2348.1.2

Lim JHC, Rahim ABA, Takeuchi I (2012) Microtripus tinggiensis, new genus and species (Amphipoda: Caprellidea: Phtisicidae) from Pulau Tinggi, East Johor Islands Archipelago, Malaysia. Proceedings of the Biological Society of Washington 125: 241-251. https://doi. org/10.2988/11-40.1

Lim JHC, Othman BHR, Takeuchi I (2015) Description of Orthoprotella bicornis, new species, and Paraprotella teluksuang, new species (Crustacea: Amphipoda) from Johor, Malaysia with special reference to unusual sexual bias towards females in Paraprotella. Raffles Bulletin of Zoology 63: 33-48.

Lim JHC, Azman BAR, Takeuchi I, Othman BHR (2017) Pseudaeginella telukrimau sp. nov., a new species of caprellid (Crustacea: Amphipoda) from Malaysia. Zootaxa 4282: 62-72. https://doi.org/10.11646/zootaxa.4282.1.3

Mayer P (1903) Die Caprelliden der Siboga-Expedition. Siboga-Expeditie 34: 1-160. https:// doi.org/10.5962/bhl.title.53742

Mayer P (1912) Caprellidae. In: Michaelsen W, Hartmeyer R (Eds) Die Fauna Sudwest-Australiens 4: 1-14.

Maritime Institute of Malaysia (2006) Malaysia national coral reef report. UNEP-GEF South China Sea Project and Marine Park Section. Ministry of Natural Resources and Environment, Malaysia, 83 pp.

Othman BHR, Azman BAR (2007) A new species of Talitridae (Amphipod: Gammaridea) from Tioman Island, Malaysia. Zootaxa 1454:59-68. https://doi.org/10.11646/zootaxa.1454.1.5

Soler-Hurtado MM, Guerra-García JM (2016) The Caprellid Aciconula acanthosoma (Crustacea: Amphipoda) Associated with Gorgonians from Ecuador, Eastern Pacific. Pacific Science 70: 73-82. https://doi.org/10.2984/70.1.6

Utinomi H (1969) Caprellids from Kamae Bay, northeastern Kyushu (Amphipoda; Caprellidae). Publications of the Seto Marine Biological Laboratory 16(5): 295-306. https://doi. org/10.5134/175557 